\title{
Hybrid poplar pulpwood production trials in southeastern Ontario
}

Ontario's poplar breeding program is especially important for southeastern Ontario where regional deficiencies of pulpwood have developed. Such deficiencies can be overcome by short-rotation plantations of high-yielding hybrid poplar, established close to the mills and under conditions that permit mechanized harvesting.

Hybrid poplar clones are well suited for short rotation plantations in southeastern Ontario. The ecological conditions are right. The vegetative propagation of hybrid poplar is easy. Its growth is fast, and its reaction to improved site conditions significant.

Test plantations of hybrid poplar have shown fast growth and high yields on many sites in southern Ontario. The average annual height increment of hybrid aspen at $7-15$ years of age was $3.3-5.7 \mathrm{ft}$ and diameter increment (at breast height) was 0.50 and 0.61 inches. The yield of hybrid aspen compares very favorably to the yield of native aspen on site class I. (It must be noted, however, that the yield tables for Ontario ${ }^{1}$ refer to unmanaged aspen stands and that they do not indicate the growth which could be obtained in managed aspen stands.) For example, the average DBH of 9- to 15-yearold plantations is similar to that of 35- to 50year-old natural stands, and the average height of trees in these plantations is similar to that of 30-year-old trees in natural stands. The mean annual increment (MAI) of the unman-

'Plonski, W. L. 1960. Normal yield tables. Ontario Dep. Lands Forests, Silvicult. Ser. Bull. No. 2. 39 p.

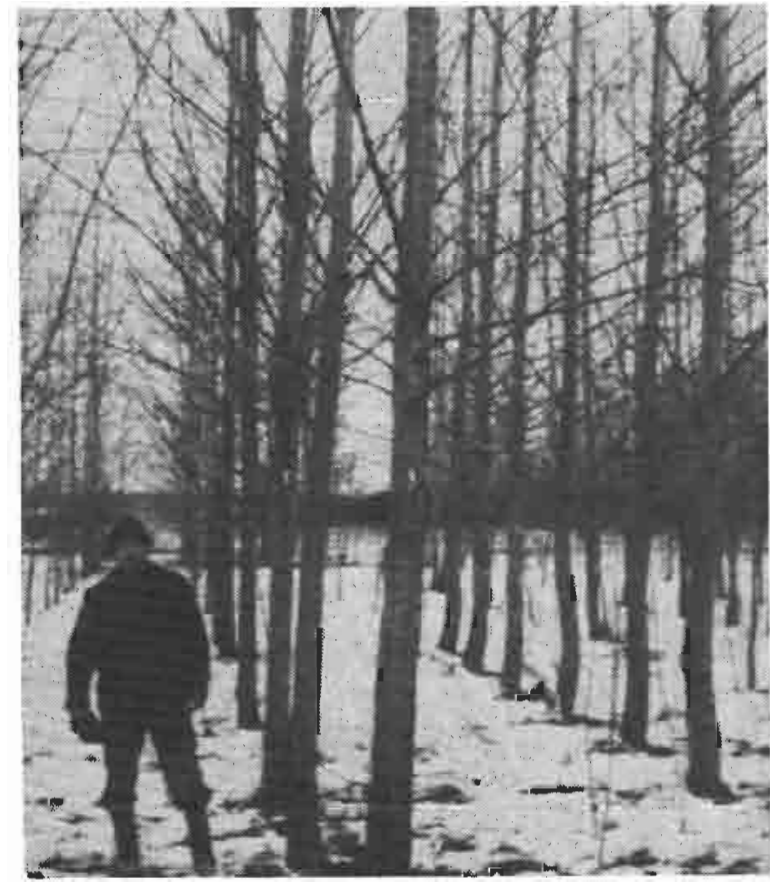

Foreground: 9 year-old hybrid aspen. aged natural stands reaches a maximum of $109 \mathrm{ft}^{3} /$ acre at 55 years of age, while in plantations MAl's between 103 and $292 \mathrm{ft}^{3} /$ acre were attained between 7 and 15 years of age. Hybrid cottonwood plantations show promise of similar excellent yields.

Wood samples from test plantations of hybrid poplar were analysed for pulp quality by the Domtar Laboratories, who were particularly interested in the project. The samples were pulped by the magnesium-bi-sulphite (magnefite) and refiner groundwood processes and gave very satisfactory results. The pulp yield and quality proved to be similar or superior to those of locally grown poplar and mixed hardwoods typical of their Cornwall mill's present furnish. The samples were of acceptable pulping quality and no particular problems were expected if similar material was used on a much larger scale.

The excellent growth and acceptable pulping qualities justified the initiation of large scale pulpwood production trials in Southeastern Ontario. They began with 75 acres planted in 1972 and more than 100 acres were prepared for planting early this year. The field staff of the Ministry of Natural Resources initiates and manages these plantations; the local pulpmills are interested and support the project.

The plantation sites are prepared by ploughing. One-foot-long unrooted stem cuttings are used as planting stock, spaced at $9 \times 9 \mathrm{ft}$ or $10 \times 10 \mathrm{ft}$; the sites will be cultivated for at least 3 years after planting. It is hoped that trees of $6-8$ inches $\mathrm{dbh}$ and 40 to $50 \mathrm{ft}$ tall can be produced in 10 years or less, and that the plantations will yield $2500-3000 \mathrm{ft}^{3} /$ acre of wood. The plantations will be regenerated by coppices or suckers.

The planting stock for the production trials is propagated in the Nurseries of the Ontario Ministry of Natural Resources. At present, the cuttings of seven hybrid cottonwood clones and five hybrid aspen clones are produced. Six of the hybrid cottonwood clones originated in Europe ( $P$ x euramericana (Dode) Guinier selections) and one in Ontario. The hybrid aspen clones were bred in Ontario. All clones were selected for production trials on the basis of their outstanding performance in clonal tests in Ontario. Information gathered from new test plantations, established under various site and management conditions, will allow for a continuous change to new and better clones and management practices.

L. Zsuffa

Forest Research Branch Ontario Ministry of Natural Resources Maple, Ontario 